
PERAN IMIGRASI TERHADAP TINDAK PIDANA KORUPSI SEBAGAI
KEJAHATAN TRANSNASIONAL TERORGANISIR BERDASARKAN PERSPEKTIF UNTOC

\title{
(THE ROLE OF IMMIGRATION TOWARD THE CRIMINAL ACTS OF CORRUPTION AS ORGANIZED TRANSNATIONAL CRIME BASED ON UNTOC'S PERSPECTIVE)
}

\author{
Jayadi Al Amien \\ Politeknik Imigrasi \\ Email: jayadialamien138@gmail.com \\ Wisnu Widayat \\ Politeknik Imigrasi \\ wisnu@poltekim.ac.id
}

\begin{abstract}
ABSTRAK
Tujuan dilakukan penelitian ini untuk mengetahui latar belakang secara yuridis di Indonesia bahwa Tindak Pidana Korupsi merupakan Kejahatan Transnasional berdasarkan United Nations Against Transnational Organized Crime (UNTOC) dan United Nations Against corruption (UNCAC) yang dituangkan dalam Undang-Undang Nomor 7 Tahun 2006 yang merupakan komitmen pemerintah untuk memerangi tindak Pidana Korupsi. Dengan menggunakan metode penelitian normatif-empiris bahwa pentingnya sinergitas dan tanggung jawab instansi-instansi yang menangani Tindak Pidana Korupsi bekerja sama dengan Direktorat Jenderal Imigrasi dalam melaporkan penetapan keputusan, permintaan, dan perintah pencegahan tersangka koruptor agar tidak dapat melarikan diri ke luar wilayah Republik Indonesia sebagaimana pencegahan diatur dalam Pasal 91 Undang-undang Nomor 6 Tahun 2011 tentang Keimigrasian.
\end{abstract}

Kata Kunci : Korupsi, Keimigrasian, Kejahatan Transnasional

\section{ABSTRACT}

The purpose of this research is to find out the juridical background in Indonesia that the Crime of Corruption is a Transnational Crime based on the United Nations Against Transnational Organized Crime (UNTOC) and the United Nations Against Corruption (UNCAC) as outlined in Law Number 7 of 2006 which is a commitment government to combat the Corruption Crime. By using the normative-empirical research method, the importance of synergy and the responsibility of agencies dealing with Corruption in collaboration with the Directorate General of Immigration in reporting decisions, requests and orders to prevent corrupt suspects from escaping outside the territory of the Republic of Indonesia as prevention is regulated in Article 91 of Law Number 6 Year 2011 concerning Immigration.

Keywords: Corruption, Immigration, Transnational Crime 


\section{A. PENDAHULUAN \\ 1. Latar Belakang}

Tindak pidana korupsi di Indonesia selalu berkembang dan terus meningkat seiring berjalannya waktu serta merupakan kejahatan luar biasa yang tidak hanya menjadi permasalahan nasional melainkan telah menjadi kejahatan transnasional pada prakteknya. Meningkatnya jumlah kasus diiringi juga dengan jumlah kerugian negara yang sangat besar stabilitas perekonomian negara. Salah satu faktor yang menyebabkan tingginya kasus korupsi adalah kemampuan koruptor atau tersangka kasus korupsi untuk melarikan diri dari Indonesia sebagai upaya menghindari proses penegakan hukum di Indonesia. Contoh kasus berhasilnya tersangka koruptor kabur ke suatu negara adalah Paulus Tanos yang merupakan mantan Direktur Utama PT Sandila Arthapura yang merupakan tersangka proyek e-KTP yang berhasil melarikan diri ke Singapura untuk menghindari proses pengadilan di Indonesia. Tentunya pemilihan negara Singapura dikarenakan belum ditandatanganinya perjanjian Ekstradisi antara Indonesia dengan Singapura yang dimanfaatkan oleh para koruptor untuk melarikan diri dan berlindung di Singapura.

Pada prakteknya wewenang penanganan kasus korupsi dan penetapan tersangka koruptor dapat dilakukan oleh 3 (tiga) instansi yang menangani kasus korupsi sesuai dengan peraturan perundang-undangan instansi terkait yaitu Kepolisian Republik Indonesia, Kejaksaan Agung Republik Indonesia, dan Komisi Pemberantasan Korupsi yang mempunyai wewenang untuk mengajukan permintaan pencegahan kepada Imigrasi. Dalam menghadapi masalah tersebut Imigrasi berperan penting sebagai penjaga pintu gerbang negara terhadap lalu lintas orang keluar dan masuk wilayah Republik Indonesia di Tempat Pemeriksaan Imigrasi baik di Bandar Udara maupun Pelabuhan serta Pos Lintas Batas dalam mencegah seseorang yang masuk dalam daftar pencegahan untuk keluar wilayah Republik Indonesia, diatur dalam pasal 91 ayat (2) yaitu Menteri melaksanakan Pencegahan berdasarkan keputusan, permintaan, dan perintah dari Instansi yang terkait sesuai dengan ketentuan peraturan perundang-undangan.

\section{Rumusan Masalah}

Adapun rumusan masalah berdasarkan latar belakang diatas adalah sebagai berikut :

1. Bagaimana Tindak Pidana Korupsi sebagai Kejahatan Transnasional berdasarkan Perspektif Hukum?

2. Bagaimana peran Imigrasi dengan instansi terkait dalam Mencegah Pelaku Tindak Pidana Korupsi Melarikan Diri ke Luar Negeri?

\section{Tujuan penelitian}

Penulisan ini bertujuan untuk mengetahui Tindak Pidana Korupsi sebagai kejahatan transnasional serta mengetahui bagaimana peran Imigrasi dalam penanganan tindak Pidana Korupsi di Indonesia berdasarkan Undang-Undang Nonomor 6 Tahun 2011 tentang Keimigrasiaan.

\section{Teori dan Dasar Hukum}

Menurut Mokhammad Najih (2019) 
"Korupsi adalah kejahatan luar biasa (extra ordinary crime) yang memiliki sifat dan karakteristik sebagai kejahatan internasional (international crime) sebagaimana yang tertuang dalam United Nations Convention Against Corruption (UNCAC) yang telah diratifikasi"

Komisi Pemberantasan Korupsi memiliki Kewenangan dalam melakukan pencegahan kepada tersangka koruptur agar tidak dapat melarikan diri ke luar negeri diatur dalam Pasal 12 Ayat (2) huruf a Undang-undang No. 19 Tahun 2019 tentang Komisi Pemberantasan Korupsi bahwa dalam melaksanakan tugas penyelidikan, penyidikan, dan penuntutan sebagaimana dalam Pasal 6 huruf c, Komisi Pemberantasan Korupsi berwenang :

"memerintahkan kepada instansi yang terkait untuk melarang seseorang bepergian ke luar negeri"

Berdasarkan penjelasan atas Undang-Undang Nomor 6 Tahun 2011 tentang Keimigrasian bahwa, "Negara Republik Indonesia menjadi salah satu negara peserta yang telah mendatangani konvensi tersebut antara lain Konvensi Perserikan Bangsa-Bangsa melawan kejahatan Transnasional yang Terorganisasi,2000, atau United Nations Convention Against Transnational Organized Crime, 2000, yang telah diratifikasi dengan Undang-Undang Nomor 5 Tahun 2009....."

\section{B. METODE PENELITIAN \\ 1. Pendekatan}

Jenis pendekatan pada penelitian ini yaitu dengan penelitian hukum normatif baik Internasional serta Nasional yang bersifat kualitatif berdasarkan penelitian kepustakaan yang diberkaitan dengan Keimigrasian baik secara langsung maupun tidak langsung.

\section{Metode Pengumpulan Data}

Metode yang digunakan dalam pengumpulan data sekunder yang diambil dari sumber-sumber dalam penelitian yaitu dengan cara mengidentifikasi peraturan perundang-undangan, berbagai tulisan dan karya ilmiah seperti (buku, literatur, hasil penelitian, jurnal ilmiah, dan lain sebagainya) serta sumber-sumber lainnya yang berkaitan dengan penelitian ini.

\section{Teknik Analisa Data}

Teknik analisa data yang digunakan dalam penelitian adalah teknis Analisa data normatif yang berkaitan dengan permasalahan pokok peneltian dengan menggunakan metode menginterpretasikan bahan-bahan hasil penelitian berdasarkan sumber hukum dengan dikaitkan dengan fakta-fakta (legal facts) yang terjadi dan dikaitkan dengan sumber hukum.

\section{PEMBAHASAN}

1. Tindak Pidana Korupsi sebagai Kejahatan Transnasional

\footnotetext{
${ }^{1}$ Indonesia. Undang-Undang tentang Perubahan kedua atas Undang-Undang Nomor 30 Tahun 2002 tentang Komisi Pemberantasan Korupsi, UU No. 30 Tahun 2002, Pasal 12
} 
Secara harafiah berdasarkan Kamus Besar Bahasa Indonesia (KBBI), Korupsi adalah "Penyelewengan atau penyalahgunaan uang negara atau perusahaan, untuk kepentingan pribadi atau orang lain"2 sedangkan pengertian Korupsi berdasarkan Undang-undang Nomor 20 Tahun 2001 tentang Perubahan Atas Undang-Undang Nomor 31 Tahun 1999 tentang Pemberantasan Tindak Pidana Korupsi yaitu "tindakan melawan hukum dengan maksud memperkaya diri sendiri, orang lain, atau korupsi yang berakibat merugikan negara atau perekonomian negara"

Tindak pidana korupsi telah digolongkan sebagai kejahatan luar biasa hal tersebut dikarenakan kejahatan korupsi semakin berkembang dan meluas yang tidak hanya mengakibatkan kerugian keuangan negara namun, berdampak pada pada melambatnya pertumbuhan perekonomian suatu negara, meningkatkan kemiskinan, serta berpengaruh besar terhadap hak-hak sosial masyarakat. Dalam pemberantasan tindak pidana korupsi tidak hanya merupakan permasalahan besar suatu negara secara nasional melainkan menjadi salah satu prioritas masyarakat Internasional.

Tindak pidana korupsi merupakan salah satu prioritas dalam Konvensi Palermo pada tahun 2000 tentang United Narions Convention Against Transnational Organized Crime (UNTOC) yang merupakan Konvensi dalam PBB yang menentang tindak Pidana Transnasional terorganisir yang tertuang pada pasal 8 konvensi tersebut. Dicantumkannya tindak pidana korupsi dalam Konvensi tersebut didasari karena korupsi tidak hanya berdampak secara nasional melainkan menjadi permasalahan secara transnasional dengan skala yang besar dan berkaitan terutama pada tindak pidana money laundering (pencucian uang). Tindak pidana korupsi pada dewasa ini merupakan Predicate crime (kejahatan asal) untuk melancarkan atau memfasilitasi tindak pidana lain seperti money laundering bahkan kejahatan yang bersifat melanggar Hak Asasi Manusia seperti crime of genocide (kejahatan genosida). ${ }^{3}$

Pada pasal 2 huruf a naskah Konvensi Palermo tahun 2000 tentang Transnational Organized Crime menjelaskan korupsi dikategorikan sebagai kejahatan transnasional yaitu :

"Organized criminal group : shall mean a structured group of three or more persons, existing for a period of time and acting in concert with the aim of committing one or more serious crimes or offences established in accordance with this Convention, in order to obtain, directly or indirectly, a financial or other material benefits"

Berdasarkan definisi tersebut bahwa kejahatan terorganisir memiliki unsur sebagai berikut :

1. Adanya suatu kelompok yang terstruktur pada periode waktu tertentu terdiri dari tiga atau lebih anggota kelompok tersebut;

2. Melakukan kejahatan berdasarkan konvensi tersebut;

3. Memiliki tujuan yaitu memperoleh keuntungan secara finansial baik langsung ataupun tidak langsung ${ }^{4}$

\footnotetext{
${ }^{2}$ KBBI Online (2021). KBBI. https://kbbi.web.id/korupsi, diakses pada Hari Minggu, 11 April 2021 Pukul 11.00 WIB.

${ }^{3}$ Dadang Siswanto, “ Korupsi Sebagai Bentuk Kejahatan Transnasional Terorganisir” hal. 125.

${ }^{4}$ Ibid, Hal 126.
} 
Lebih lanjutnya korupsi merupakan kejahatan transnasional ditegaskan dalam pembukaan isi konvensi United Nations Convention Against Corrruption pada tahun 2003 yaitu ${ }^{5}$

"The States Parties to this Convention, Concerned about the seriousness of problems and threats posed by corruption to the stability and security of societies, undermining the institutions and values of democracy, ethical values and justice and jeopardizing sustainable development and the rule of law"

Bahwa ancaman korupsi itu sendiri merupakan masalah yang sangat serius mengakibatkan terganggunya stabilitas dan keamanan suatu negara serta dapat merusak fungsi dari Lembaga-lembaga negara dan merusak nilai-nilai demokrasi serta keadilan suatu negara. Selain itu, korupsi juga berdampak terhadap terhambatnya pembangunan berkelanjutan suatu negara dan penegakan hukum yang dilakukan oleh aparat penegak hukum. Kejahatan korupsi dapat menjadi akar dari setiap permasalahan suatu negara seperti ekonomi, sosial, politik, serta budaya suatu negara itu sendiri.

Pemerintah Indonesia meratifikasi United Convention Against Corruption tahun 2003 ke dalam Undang-Undang Nomor 7 Tahun 2006 yang merupakan komitmen pemerintah untuk memerangi tindak Pidana Korupsi yang terus berkembang dan berskala internasional serta mendorongnya kerja sama internasional dalam pencegahan dan pemberantasan tindak pidana konvensi berdasarkan konvensi tersebut.

Indonesia telah mempunyai sejumlah undang-undang yang substansinya terkait dengan Konvensi UNTOC dan UNCAC pada Peraturan perundang-undangan nasional dalam usaha melawan tindak pidana korupsi telah dibuat oleh Lembaga berwenang Indonesia, antara lain Undang-Undang Nomor 31 Tahun 1999 tentang Pemberantasan Tindak Pidana Korupsi dan telah diubah dengan diberlakukannya Undang-Undang Nomor 20 Tahun 2001 tentang Perubahan atas Undang-Undang Nomor 31 Tahun 1999 tentang Pemberantasan Tindak Pidana Korupsi, selain itu terdapat Undang-Undang Nomor 30 Tahun 2002 tentang Komisi Pemberantasan Tindak Pidana Korupsi dan telah diubah dengan diberlakukannya Undang-Undang Nomor 19 Tahun 2019 tentang Perubahan Kedua atas Undang-Undang Nomor 30 Tahun 2002 tentang Komisi Pemberantasan Tindak Pidana Korupsi. ${ }^{6}$

Pengertian Komisi Pemberantasan Korupsi Berdasarkan Undang-Undang Nomor 19 tahun 2019 tentang Komisi Pemberantasan Korupsi (KPK) adalah "Lembaga negara dalam rumpun kekuasaan eksekutif yang melaksanakan tugas pencegahan dan pemberantasan Tindak Pidana Korupsi sesuai dengan Undang-Undang ini." Berdasarkan pasal 6 Undangundang KPK Komisi Pemberantasan Korupsi (KPK) memiliki tugas dan fungsi menangani Tindak pidana korupsi dengan melakukan penyeldikan, penyidikan, dan penuntutan serta

\footnotetext{
${ }^{5}$ Lihat Preambule UN Convention Against Corruption 2003 Alenia Kesatu.

${ }^{6}$ Eliza Wulandari, M.J Barimbing. "Pencegahan dan Penangkalan : Teknis Substantif Bidang Keimigrasian” BPSDM KUMHAM Press. 2020.

${ }^{7}$ Indonesia. Undang-Undang tentang Perubahan kedua atas Undang-Undang Nomor 30 Tahun 2002 tentang Komisi Pemberantasan Korupsi, UU No. 30 Tahun 2002, Pasal 1
} 
pencegahan namun, dibatasi pada tindak pidana korupsi berdasarkan perundang-undangan yang mengatur ${ }^{8}$

Berbagai Lembaga-lembaga negara yang mempunyai wewenang terkait penanganan dan pemberantasan tindak pidana korupsi. Kepolisian Republik Indonesia (POLRI) mempunyai tugas dan fungsi untuk melakukan proses penyelidikan dan penyidikan tindak pidana korupsi dalam hal tertentu yang mengacu pada Undang-undang Nomor 8 Tahun 1981 tentang Hukum Acara Pidana (KUHAP). Selain itu Kejaksaan Republik Indonesia memiliki tugas dan fungsi melakukan penyidikan Tindak Pidana Korupsi berdasarkan Undang-Undang Nomor 16 Tahun 2004 tentang Kejaksaan yang dijelaskan pada pasal 30 Undang-Undang tersebut untuk melakukan penyidikan terhadap tindak pidana korupsi. Komisi Pemberantasan Korupsi merupakan Lembaga Independen yang disebut sebagai Lembaga super body institusi dalam hal penegakan hukum tindak pidana korupsi yang mendapatkan pembenaran juridis menjalankan Undang-Undang nomor 19 Tahun 2019 tentang Komisi Pemberantasan Korupsi.

KPK, kejaksaan, dan Kepolisian memiliki fungsi investigasi Fungsi investigasi dijalankan oleh KPK, Kejaksaan, dan Kepolisian. KPK memiliki kewenangan menangani kasus korupsi perkara tinggi namun kejaksaan memiliki kewenangan dalam investigasi tindak pidana korupsi di bawah pengawasan KPK serta perkara tersebut dapat diambil ahli oleh KPK. Selain itu investigasi terjada[ tindak pidana terhadap pemegang jabatan pimpinan tinggi tidak diperlukan izin tertulis kepada Menteri dalam Negeri atau presiden. Selain itu peran PPTAK (Pusat pelaporan dan analisis di Indonesia) sebagai unit intelijen keuangan di Indonesia yang membantu penanganan tindak pidana korupsi oleh KPK, Kejaksaan, dan Kepolisian. ${ }^{9}$

Berdasarkan pasal 29 ayat (1) Konvensi United Nations Against Transnational Organized Crime.

"Each State Party shall, to the extent necessary, initiate, develop or improve specific training programmes for its law enforcement personnel, including prosecutors, investigating magistrates and customs personnel, and other personnel charged with the prevention, detection and control of the offences covered by this Convention. Such programmes may include secondments and exchanges of staff." 10

Bahwa setiap negara pihak konvensi harus berusaha untuk mengembangkan program-program khusus bagi aparat penegak hukum yang bertanggung jawab terhadap upaya pencegahan, pendeteksian, dan pengawasan atas kejahatan yang diatur dalam konvensi tidak hanya instansi terkait yang menangani Tindak Pidana Korupsi dalam hal penyelidikan dan penuntutan melainkan fungsi pengawasan dari instansi yang berwenang. Pengawasan atas kejahatan suatu tindak pidana transnasional yang hendak melarikan diri ke luar wilayah Indonesia dapat dilakukan oleh Pejabat Imigrasi di Tempat Pemeriksaan Imigrasi dan Pos Lintas Batas untuk dilakukan pencegahan. Program-program khusus aparat penegak hukum harus saling bersinergi antara Imigrasi dengan Instansi terkait seperti Kepolisian,

\footnotetext{
${ }^{8}$ Indonesia. Undang-Undang tentang Perubahan kedua atas Undang-Undang Nomor 30 Tahun 2002 tentang Komisi Pemberantasan Korupsi, UU No. 30 Tahun 2002, Pasal 11

${ }^{9}$ Buku Komitmen Indonesia pada United Nations Convention Against Corruption (UNCAC) dan G20 AntiCorruption Working Group (ACWG) Tahun 2012-2018 : Indonesia Executive Summary Review Putaran I

${ }^{10}$ Konvensi Tahun 2000 PBB Melawan Kejahatan Transnasional Terogrnasisir, Pasal 29.
} 
Kejaksaan, imigrasi, dan Komisi Pemberantasan Korupsi dalam mencegah pelaku tindak pidana Korupsi kabur ke luar negeri.

\section{Peran Imigrasi terhadap Pelaku Tindak Pidana Korupsi}

Keimigrasiaan melaksanakan penegakan kedaulatan atas Wilayah Indonesia dalam rangka ketertiban kehidupan bangsa dan negara yang memilik tugas menjaga pintu gerbang negara terkait lalu lintas orang yang masuk atau keluar Wilayah Indonesia. Terkait fungsi Keimigrasian dalam rangka yang berupa upaya penegakan hukum dilakukan di sepanjang garis perbatasan Wilayah Indonesia dilaksanakan oleh Pejabat Imigrasi yang meliputi Tempat Pemeriksaan Imigrasi dan Pos Lintas Batas diatur dalam Undang-Undang Nomor 6 Tahun 2011 tentang Keimigrasian.

Berdasarkan Undang-Undang Nomor 6 Tahun 2011 tentang Keimigrasian pasal 9 ayat (1) "setiap orang yang masuk atau keluar Wilayah Indonesia wajib melalui pemeriksaan yang dilakukan oleh Pejabat Imigrasi di Tempat Pemeriksaan Imigrasi” . dalam hal ini peran Imigrasi dalam mencegah atau menolak orang untuk keluar wilayah Indonesia dilakukan oleh Pejabat Imigrasi di Tempat Pemeriksaan Imigrasi. Berdasarkan pasal 16 Undang-Undang Nomor 6 Tahun 2011 tentang Keimigrasian menyebutkan. ${ }^{11}$

(1) Pejabat Imigrasi menolak orang untuk keluar Wilayah Indonesia dalam hal orang tersebut:

a. tidak memiliki Dokumen Perjalanan yang sah dan masih berlaku;

b. diperlukan untuk kepentingan penyelidikan dan penyidikan atas permintaan pejabat yang berwenang; atau

c. namanya tercantum dalam daftar Pencegahan.

(2) Pejabat Imigrasi juga berwenang menolak Orang Asing untuk keluar Wilayah Indonesia dalam hal Orang Asing tersebut masih mempunyai kewajiban di Indonesia yang harus diselesaikan sesuai dengan ketentuan peraturan perundang-undangan.

Warga Negara Indonesia dapat dilakukan pencegahan keluar Wilayah Indonesia Berdasarkan alasan tertentu untuk jangka waktu tertentu. Dalam hal pencegahan Menteri bertanggung jawab melakukan pencegahan yang diatur dalam Undang-Undang Nomor 6 Tahun 2011 tentang Keimigrasian pasal $91 .^{12}$

(1) Menteri berwenang dan bertanggung jawab melakukan Pencegahan yang menyangkut bidang Keimigrasian.

(2) Menteri melaksanakan Pencegahan berdasarkan:

a. hasil pengawasan Keimigrasian dan keputusan Tindakan Administratif Keimigrasian;

b. Keputusan Menteri Keuangan dan Jaksa Agung sesuai dengan bidang tugasnya masing-masing dan ketentuan peraturan perundang-undangan;

c. permintaan Kepala Kepolisian Negara Republik Indonesia sesuai dengan ketentuan peraturan perundang-undangan;

d. perintah Ketua Komisi Pemberantasan Korupsi sesuai dengan ketentuan peraturan perundangundangan;

\footnotetext{
${ }^{11}$ Indonesia. Undang-Undang tentang Keimigrasian, UU No. 6 Tahun 2011, Pasal 16.

12 Indonesia. Undang-Undang tentang Keimigrasian, UU No. 6 Tahun 2011, Pasal 91.
} 
e. permintaan Kepala Badan Narkotika Nasional sesuai dengan ketentuan peraturan perundangundangan; dan/atau

f. keputusan, perintah, atau permintaan pimpinan kementerian/lembaga lain yang berdasarkan undang-undang memiliki kewenangan Pencegahan.

(3) Menteri Keuangan, Jaksa Agung, Kepala Kepolisian Negara Republik Indonesia, Ketua Komisi

Pemberantasan Korupsi, Kepala Badan Narkotika Nasional, atau pimpinan kementerian/ lembaga yang memiliki kewenangan Pencegahan sebagaimana dimaksud pada ayat (2) huruf $f$ bertanggung jawab atas keputusan, permintaan, dan perintah Pencegahan yang dibuatnya.

Pencegahan terhadap Warga Negara Indonesia yang akan melakukan perjalanan ke luar negeri didasarkan pada Surat Keputusan pencegahan dari instansi yang berkepentingan sesuai dengan ketentuan peraturan perundang-undangan masing-masing instansi yang meminta kepada Menteri Hukum dan HAM melalui Dirjen Imigrasi agar nama yang diminta pencegahan dimasukkan ke dalam daftar pencegahan dan untuk melaksanakan pencegahan sehingga menutup peluang orang yang telah dicegah lolos dari Tempat Pemeriksaan Imigrasi dan Pos Lintas Batas.

Dalam keadaan tertentu atau mendesak pejabat dari instansi yang mengajukan pencegahan kepada Menteri Hukum dan HAM dapat meminta langsung kepada Pejabat Imigrasi tertentu untuk melakukan pencegahan terhadap seseorang dengan alasan yang dapat diterima agar tidak dapat berpergian ke luar wilayah Republik Indonesia. Berdasarkan Pasal 94 Undang-Undang Nomor 6 Tahun 2011 ditentukan bahwa, Pencegahan ditetapkan dengan keputusan tertulis. Dan memuat sekurang-kurangnya identitas orang yang terkena pencegahan; alasan pencegahan; dan jangka waktu pencegahan. Keputusan pencegahan yang dimaksud disampaikan kepada orang yang terkena pencegahan selambat-lambatnya 7 (tujuh) hari terhitung sejak tanggal keputusan penetapan. Pada ayat (7) Pasal 94 Undangundang Nomor 6 Tahun 2011 bahwa identitas orang yang dikenai keputusan pencegahan ke dalam daftar Pencegahan melalui Sistem Informasi Manajemen Keimigrasian oleh Menteri atau Pejabat Imigrasi yang ditunjuk dan orang yang masuk dalam daftar pencegahan wajib ditolak untuk keluar Wilayah Indonesia oleh Pejabat Imigrasi.

Pengaturan lebih lanjut terkait tata cara tentang pencegahan diatur dalam Peraturan Pemerintah Republik Indonesia Nomor 30 Tahun 1994 tentang tata cara Pelaksanaan Pencegahan dan Penangkalan dijelaskan bahwa, Keputusan pencegahan dan penangkalan sebagaimana dimaksud dalam Pasal 2 dan Pasal 3 ayat (1) dan ayat (2) harus memuat identitas orang yang dikenakan pencegahan atau penangkalan yang meliputi sekurangkurangnya:
a. Nama;
b. Umur;
c. Pekerjaan;
d. Alamat;
e. Jenis kelamin; dan
f. Kewarganegaraan 
Komisi Pemberantasan Korupsi dapat memerintah instansi melakukan pencegahan terhadap seseorang untuk berpergian ke luar negeri apabila seseorang dalam proses penyelidikan, penyidikan, dan penuntutan tindak pidana Korupsi yang diatur dalam Pasal 12 ayat (1) huruf b Undang-Undang Nomor 30 Tahun 2002 tentang Komisi Pemberantasan Korupsi yang selanjutnya dipertegas dalam Pasal 91 ayat (2) huruf d Undang-Undang Nomor 6 Tahun 2011 tentang Keimigrasian bahwa Ketua Komisi Pemberantasan Korupsi dapat menetapkan pencegahan dan menyampaikan kepada Meneteri Hukum dan HAM melalui Direktorat Jenderal Imigrasi. Selama tahun 2019, KPK telah melakukan pelaksanaan perintah pencegahan sejumlah 133 (serratus tiga puluh tiga) yang terdiri dari 106 (serratus enam) permohonan pencegahan baru, dan 26 ( dua puluh enam) permohonan perpanjangan, dan 1 (satu) permohonan pencabutan pencegahan. ${ }^{13}$

Kejaksaan Republik Indonesia melalui Jaksa Agung mempunyai tugas dan wewenang untuk dapat mencegah atau menangkal orang tertentu untuk masuk atau keluar Wilayah Republik Indonesia apabila terlibat dalam perkara pidana sesuai dengan peraturan perundang-undangan terkait yang diatur dalam Undang-undang Nomor 16 Tahun 2004 tentang Kejaksaan Republik Indonesia pasal 35 huruf f. Dalam Undang-Undang Nomor 6 Tahun 2011 tentang Keimigrasian Pasal 91 Ayat (2) huruf b juga menjelaskan Keputusan Jaksa Agung berdasarkan bidang dan tugasnya dengan ketentuan peraturan perundangundangan terkait. Pelaksanaan keputusan pencegahan yang diajukan oleh Kejaksaan Agung pada tahun 2019 sebanyak 206 (dua ratus enam) permintaan pencegahan. ${ }^{14}$

Kepolisian Republik Indonesia juga mempunyai wewenang yang sama untuk melakukan pencegahan terhadap seseorang yang diatur dalam Pasal 26 Peraturan Kepala Kepolisan Negara Republik Indonesia (Perkapolri) Nomor 6 Tahun 2019 tentang Penyidikan Tindak Pidana, apabila seseorang telah ditetapkan sebagai tersangka agar tidak dapat melarikan diri keluar wilayah negara Indonesia selain itu, dalam keadaan yang mendesak dan dinilai sangat perlu untuk kepentingan penyidikan. Seorang penyidik pada tahap awal dapat mengajukan permintaan secara langsung kepada pejabat Imigrasi untuk melakukan pencegahan keluar negeri terhadap seseorang yang diduga melakukan tindak pidana. Sedangkan dalam Undang-undang Nomor 6 Tahun 2011 tentang Keimigrasian Pasal 91 ayat (2) huruf c, bahwa permintaan Kepala Kepolisian Negara Republik Indonesia untuk pencegahan terhadap seseorang dengan ketentuan peraturan perundang-undangan instansi terkait.

\section{PENUTUP}

\section{Kesimpulan}

Tindak Pidana Korupsi berdasarkan United Convention Against Transnational Organized Crime dikategorikan sebagai kejahatan transnasional terogansisir yang bersifat luar biasa dan merupakan kejahatan akar yang menyebabkan terjadi kejahatan-kejahatan lainnya seperti pencucian uang. Indonesia merupakan negara pihak dari dua jenis konvensi yaitu Konvensi Palermo tahun 2000 tentang melawan Kejahatan Transnasional Teroganisir

\footnotetext{
${ }^{13}$ Eliza, Op.Cit., hal 26-27

14 Eliza Wulandari, M.J Barimbing. "Pencegahan dan Penangkalah : Teknis Substantif Bidang Keimigrasian” BPSDM KUMHAM Press. 2020. Ibid hal 22-24
} 
(UNTOC) dan Konvensi PBB Anti Korupsi (UNCAC) tahun 2003. Pemerintah Indonesia telah menuangkan tindak pidana Korupsi ke dalam Undang-Undang Nomor 20 Tahun 2001 tentang perubahan atas Undang-Undang Nomor 31 Tahun 1999 tentang Pemberantasan Tindak Pidana Korupsi. Selain itu, pembentukan Komisi Pemberantasan Korupsi (KPK) merupakan yang berkomitmen untuk penguatan lembaga anti korupsi dari tindak lanjut dari Konvensi PBB Anti Korupsi (UNCAC)

Permasalahan yang muncul di Indonesia adalah adanya kesempatan para tersangka koruptor untuk melarikan diri ke luar wilayah Republik Indonesia untuk menghindari proses penegakan hukum. Penanganan Tindak Pidana Korupsi di Indonesia dapat dilakukan oleh beberapa Instansi sesuai dengan ketentuan peraturan perundang-undangan instansi tersebut yaitu Kepolisian Republik Indonesia, Kejaksaan Agung Republik Indonesia, dan Komisi Pemberantasan Korupsi. Masing-masing instansi mempunyai tugas dan kewenangan untuk melakukan pencegahan terhadap tersangka tindak pidana Korupsi dengan melaporkan kepada Direktorat Jenderal Imigrasi. Namun kurangnya integrasi antar instansi menyebabkan jumlah kasus tindak pidana korupsi yang ditangani oleh instansi terkait berbanding jauh dengan daftar pencegahan yang diperoleh oleh Imigrasi sehingga akan membuka peluang seseorang tersangkat koruptor untuk menghindari proses penegakan hukum sebelum dilakukannya penyelidikan atau penyidikan atau penuntutan oleh instansi terkait.

\section{Saran}

Pentingya Negara Republik Indonesia menganggap permasalahan korupsi adalah prioritas utama untuk diperangi karena merupakan kejahatan asal (predicate crime) dari pencucian uang serta bedampak pada stabilitas suatu negara tidak hanya dari segi perekonomian. Perlunya sinergitas dan integrasi antar instansi yang menangani tindak pidana korupsi untuk mencegah tersangka korupsi kabur dari wilayah Republik Indonesia ke suatu negara yang dapat melindungi tersangka dari jeratan kasus korupsi yang dilakukan. Diperlukannya sistem terintegrasi antar instansi Kepolisian Republik Indonesia, Kejaksaan Agung Republik Indonesia, dan Komisi Pemberantasan Korupsi dengan Direktorat Jenderal Imigrasi berbentuk aplikasi secara online terkait pelaporan atau permintaan instansi terkait untuk melakukan pencegahan terhadap seorang yang dinyatakan tersangka yang tepat waktu ke sistem informasi Manajemen Keimigrasian (SIMKIM) guna mencegah seseorang untuk melarikan diri ke Negara lain.

\section{E. DAFTAR PUSTAKA}

\section{BUKU}

Buku Komitmen Indonesia pada United Nations Convention Against Corruption (UNCAC) dan G20 Anti-Corruption Working Group (ACWG) Tahun 2012-2018 : Indonesia Executive Summary Review Putaran I

\section{JURNAL ILMIAH}


Dadang Siswanto, “Korupsi Sebagai Bentuk Kejahatan Transnasional Terorganisir”.

Eliza Wulandari, M.J Barimbing. "Pencegahan dan PenangkalaN : Teknis Substantif Bidang Keimigrasian” BPSDM KUMHAM Press. 2020.

Herlina, A., Peran Direktorat Jenderal Imigrasi Sebagai Fasilitator Pembangunan Masyarakat dalam Skema Kerjasama IA-CEPA. NeoRespublica: Jurnal IImu Pemerintahan, 2(2), pp.115-134.

Herlina, A., 2019. The Significance of the Bali Process in Fostering Awareness of Irregular Migration in Asia Pacific Region (Doctoral dissertation, Flinders University, College of Business, Government and Law.).

Mirwanto, T., 2016. Sistem Hukum Pengawasan Tenaga Kerja Asing Terhadap Penyalahgunaan Izin Tinggal Kunjungan Untuk Bekerja Pada Perusahaan Penanaman Modal Asing Di Indonesia. Lex et Societatis, 4(3).

Purwanti, M., 2018. CLASSIFICATION OF CRIMES AND VIOLATIONS IN THE IMMIGRATION ACT. Jurnal IImiah Kajian Keimigrasian, 1(1), pp.18-30.

Purwanti, M., 2016. Kewajiban dan tanggung jawab negara dalam pemenuhan Hak Asasi Manusia. Kementerian Hukum dan HAM.

Syahrin, M.A., 2018. Menakar Kedaulatan Negara dalam Perspektif Keimigrasian. Jurnal Penelitian Hukum De Jure, 18(1), pp.43-57.

Syahrin, M.A., 2018. Teori Kebijakan Selektif Keimigrasian. Petak Norma.

Syahrin, M.A., 2016. Antara Batas Imajiner Dan Kedaulatan Negara. Imigrasi Di Batas Imajiner (TPI Soekarno Hatta), 1, pp.16-31.

Syahrin, M.A., 2015. Hak Asasi Bermigrasi. Bhumi Pura, 11(1), pp.45-48.

Setiawan, A., 2019. REINFORCEMENT THE ROLE OF INTELLIGENCE THROUGH SURVEILLANCE POSTS IN EACH WORK AREA OF THE IMMIGRATION OFFICE. Journal of Law and Border Protection, 1(1), pp.1-12.

Wardana, I.G.P.A.K., 2019. Prevention and Deterrence of Foreigners who Violate Immigration Regulations. Journal of Law and Border Protection, 1(1), pp.73-86.

Wiraputra, A.R., 2020. Tindak Pidana Perdagangan Orang Dengan Subjek Tenaga Kerja Indonesia Dalam Perspektif Hukum Keimigrasian (Doctoral dissertation, Universitas Pembangunan Nasional Veteran Jakarta).

\section{PERATURAN PERUNDANG-UNDANGAN}

Indonesia. Undang-Undang tentang Perubahan kedua atas Undang-Undang Nomor 30

Tahun 2002 tentang Komisi Pemberantasan Korupsi, UU No. 30 Tahun 2002.

Indonesia. Undang-Undang tentang Keimigrasian, UU No. 6 Tahun 2011.

Konvensi Tahun 2000 ,PBB Melawan Kejahatan Transnasional Terogrnasisir.

Konvensi Tahun 2003, PBB Melawan Korupsi. 


\section{INTERNET}

KBBI Online (2021). KBBI. https://kbbi.web.id/korupsi, diakses pada Hari Minggu, 11 April 2021 Pukul 11.00 WIB 